\title{
Efficiency of the UN action in the area of transport, environmental protection, health
}

\author{
Marina Ermolina ${ }^{1}$, Anna Matveevskaya ${ }^{1}$, and Sergey Pogodin ${ }^{2}$ \\ ${ }^{1}$ Saint-Petersburg State University, Universitetskaya Emb., 13B, St Petersburg 199034, Russia \\ ${ }^{3}$ Peter the Great St.Petersburg Polytechnic University, Polytechnicheskaya, 29, St. Petersburg, \\ 195251, Russia
}

\begin{abstract}
The paper examines the performance of the UN Economic Commission for Europe (UNECE) in the field of transport, environment and health. In the course of the study, the tasks of reviewing and summarizing the main arguments of supporters and critics of UN activities in this field and forecasting the development of its potential in the future, the institutional features of the reforms to achieve sustainable development, as well as the most important problems of the green economy are performed. The authors emphasize that in the recent 25 years environment protection has become a priority for the UN activity. Additionally, international conferences on environmental issues and sustainable development have been an important tool to define global priorities, to raise awareness about these issues and to draw attention to essential problems that can be neglected. According to the authors of this study, no matter how inspiring the tendency of the growth of the number of specialized agencies involved in solving problems of transport, environment and health, these efforts are clearly not enough. The paper substantiates the conclusion that today the UN is the only global organization with the required resources to be able to positively influence the sphere of environmental protection. At the same time, comprehensive institutional mechanisms to improve the transport system, environmental protection and the coordination of health strategy are needed within the framework of the activities of the specialized UN agencies.
\end{abstract}

\section{Introduction}

Half a century ago the environmental problem was not considered as a national threat, not to mention its global scale, which can trigger an international conflict, harm human health, economic welfare and social stability. Even the Charter of the United Nations, signed in 1945, did not touch upon environmental protection [18]. However, today the problem of environmental protection and sustainable development, based on needs of present generations and interest restrictions of future generations, is a priority for the global community. The former UN Secretary-General Ban Ki-Moon regarded this issue as the top

1 Corresponding author: annamatveevskaya@mail.ru 
priority [9]. The next UN Secretary-General has also drawn attention to this issue, calling for dealing with global challenges and reducing threats through sustainable development [1].

Evaluating the problem of human rights, it is essential to understand that today's world is increasingly fragile and interdependent. This is related not only to the possible collapse of global civilization resulting from the nuclear war caused by international conflicts. This danger occurs as a result of violations of human rights, unilateral acts of states in favor of "humanistic" purposes, new forms of terrorism. These issues along with other global challenges, i.e. world hunger solution, poverty, diseases, illiteracy, energy, environment and demography issues, require joint efforts and new political solutions, which are aimed at readiness of member-states to prioritize global problems beyond their own sovereign rights and interests.

Obviously, for the recent twenty five years environmental protection has become an important UN activity. At present, there are more than 200 international conventions on nature protection and wildlife preservation, such as UN Environment Program and Commission on Sustainable Development. However, in spite of achievements in drawing up and signing agreements, establishing various institutions to prevent environmental effects of human activities, Earth's environment keeps getting worse. Although the increase in a number of specialized UN institutions, involved in environmental protection, is significant, these efforts are not enough.

\section{Materials and Methods}

The methodological basis of the given research is systems analysis. Using this type of analysis, the authors studied UN's environmental protection activity, whose peculiarity is complex analysis of all aspects in UN activity - environmental, political, economic. Writing this paper, the authors dealt primarily with publications in English and applied the method of content-analysis. Another important method used to analyze UN's activity to the full was the historical-comparative method. This was the method to study and compare outcomes of most important environmental conferences.

The book of William Adams «Green development» provides a clear and coherent analysis of sustainable development in both theory and practice. This book has been the theoretical basis of the presented research. The «Green development» discusses the origins of thinking about sustainability and sustainable development and its evolution to the present day, the ideas that dominate mainstream sustainable development (ecological modernization, market environmentalism and environmental economics), and offers clear insights into the challenges of environmental sustainability and social and economic development. This research work represents a synthesis of theoretical ideas on sustainability.

The «Green development» is extremely valuable for the sustainable development issue. It provides the theoretical foundation necessary for objective judgement and assessment of UN environmental protection activity. The book covers such ideas as dilemmas of sustainability, origins and evolution of the sustainability concept, preservation policy and contemporary global issues.

Another important source is the book of Tim Jackson "Prosperity without Growth". It is notable that the shift to the policy of sustainable development is one of the main goals in environmentalism. However, achievement of this goal is impossible without joint efforts with the economic sector. The given paper illustrates necessity of cooperation with environmental and economic sectors.

The basis for the given research has been works of numerous Russian and international scientists. But the latter made a greater contribution to the research. This is explained by the fact that Russia with all its achievements is still a developing country, which ensures its growth at the expense of raw materials industry. Thus, the sphere of sustainable development 
in our country is far from being a national strategic task. This is the reason for insufficient scientific elaboration. However, although the Government of the Russian Federation is not interested in promoting environmental issues and funding research in this field, this does not mean that these problems do not exist.

\section{Problem Statement}

For decades after the creation of the United Nations Organization, the conditions of the Earth's natural systems have got worse; and this trend is on the rise. The planet is threatened with global warming, deforestation, ecosystem destruction, damaging hunting and fishing. All these tendencies have grave consequences for human well-being, such as starvation of poor people, lack of pharmaceuticals, destruction of traditional fishing communities, disappearance of numerous island nations that can sink underwater as a result of global warming.

As early as 1991 American scientist David Orr described degradation of the environment in such words: "If today is a typical day on planet Earth, humans will add 15 million tons of carbon to the atmosphere, destroy 115 square miles of tropical rainforest, create 72 square miles of desert, eliminate between 40-100 species, erode 71 million tons of top soil, and increase the population by 263,000 " [32].

Since these data were published, some figures have changed, but the common trend remains stable. In the report, 2001, entitled "People and ecosystems: The fraying web of life", the World Resources Institute came to conclusion that most world's ecosystems are stressed and deteriorating [34].

It is well-known that humanity is inflicting long-term damage to the planet. Recent research of such groups as the Netherlands Environmental Assessment Agency or the Royal Society, have confirmed that the climate system and a lot of important ecosystems in the world are under threat [29]. There are also serious risks referring to the shortage of water, food and energy. It is absolutely unclear how the world will meet demands of the population, who will have accounted for none billion by 2050 . Sustainable development should become the main goal of the international environmental movement. Nevertheless, countries do not adhere to sustainability goals, not to mention the correct policy to achieve such goals and to allocate expenses.

Being concerned about this, William Rees warns that in early XXI century the human activity in great scales will lead to the global impact on the environment. Stratospheric ozone depletion affects both southern and northern hemispheres; the amount of carbon dioxide in the atmosphere has risen by $30 \%$ in the industrial epoch, and today it is at the top compared to the recent 160,000 years; average global temperature set a new record; the world suffers climate changes and frequent weather disasters; atmospheric nitrogen falls into ecosystems, namely in all natural ground processes; almost half the Earth's resources were modified by human activity; more than half the accessible fresh water on the planet is used by humans; two thirds of major fisheries in the world are fully exploited; biodiversity loss is on the increase [37].

Key sources of the present research are declarations of the three main environmental conferences. These are Stockholm Conference in 1972 - the first UN summit on the environment that put the issue on the global political agenda; the United Nations Conference on Environment and Development; and the United Nations Conference on Sustainable Development Rio+20.

The Conference 1972 produced three documents: Stockholm Declaration, Action Plan with 109 recommendations and Resolution. They are the documents which contained such basic principles as recognition of human rights for favorable environment, aspiration to 
prevent nuclear weapon threat, and plans for further cooperation. The documents launched institutionalization of international multilateral environmental interaction.

Another serious stage in developing the international environmental activity took place in June 1992, when heads of more than 100 states gathered in Rio de Janeiro at the United Nations Conference on Environment and Development. This Conference is known as the Earth Summit. By that time environmental issues had been extremely urgent. Rio de Janeiro Declaration with its 27 principles fixed most important statements, e.g. the idea of the developing world that consists of states sharing the same environmental and development problems. For most states the Declaration is one of the environmental law sources.

Finally, the outcome document which was worked out after the United Nations Conference on Sustainable Development Rio+20, held in Rio de Janeiro in 2012, "Future we want" [2]. It was the Conference to place great hopes on. However, afterwards, it was severely criticized. Therefore, the outcome documents of the three Conferences have been the foundation of this research, as taking into account the global character of the Conferences and analyzing activity of specialized institutions, it is possible to consider development and to assess the result of UN environmental protection activity.

The Inland Transport Committee, supported by the UNECE Sustainable Transport Division, implements a number of activities that have a direct impact on the achievement of the goals of the 2030 Agenda for Sustainable Development.

The UNECE strategy in the field of transport, environment and health can be traced by the example of a number of conferences and documents adopted at them:

Thus, at the Third Ministerial Conference on Environment and Health (London, 16-18 June 1999), the London Charter on Transport, Environment and Health was adopted.

The first High-level Meeting on Transport, Environment and Health (Geneva, 4 May 2001) was held to determine the next steps that need to be taken to develop transport that meets the requirements and interests of health and the environment.

The second high-level meeting on transport, environment and health was adopted in Geneva (Switzerland) on July 5, 2002, at which the Declaration was adopted.

The third high-level meeting on transport, environment and health was held in Amsterdam (Netherlands) on January 22-23, 2009, which resulted in the adoption of such an important document as the "European Transport, Environment and Health Program".

The fourth high-level meeting on transport, health and the environment (14-16 April 2014, Paris) was held under the loud title "The city on the move: first of all, the people!"

\section{Research Questions}

The solution to the above-stated problem is the concept of sustainable development, which has been a priority for the global community for decades.

In 2015 New York hosted the jubilee $70^{\text {th }}$ session of the UN General Assembly. The outcome of the session was the adopted document "Transforming our world: the 2030 Agenda for Sustainable Development" [10]. The Document set goals of sustainable development for member-states. This Conference confirms that sustainable development is an important and topical issue in today's world.

The purpose of this paper is to analyze efficiency of the sustainable development concept at both international and national levels. Consequently, we can determine several objectives of the research: 1) to present the outcome of the UN Conference on Environment and Development; 2) to analyze definition and defining principles of the sustainable development concept; 3 ) to consider efficiency of UN activity nowadays.

The concept of sustainable development is the main UN environmental strategy in the XXI century. According to this concept, social, environmental and economic spheres have to evolve simultaneously in order to achieve sustainable development, which means that the 
economic and technological situation is in line with the environmental conditions, ensuring future growth. The term was coined in 1980, when the International Union for Conservation of Nature and Natural Resources launched the World Conservation Strategy in order to achieve sustainable development via conservation of living resources. Later the UN Environmental Program (UNEP) started promoting this concept. Nairobi Declaration, adopted at the $19^{\text {th }}$ UN General Assembly in June 1997, states that UNEP "has been and should continue to be the principal United Nations body in the field of the environment ...the role of UNEP is to be the leading global environmental authority that sets the global environmental agenda, that promotes the coherent implementation of the environmental dimension of sustainable development within the United Nations system and that serves as an authoritative advocate for the global environment"'[8]. Later there were other acts and resolutions of the UN General Assembly with similar propositions, in particular, Resolution No. A/RES/S-19/2 [11], adopted on September 19, 1997 by the UN General Assembly at the $19^{\text {th }}$ Special Session, and Malta Declaration, 2000 [4].

Initially, UNEP included the following priority areas:

1. Help for the poor, as they are hit hardest by environmental degradation.

2. Idea of independent development in the conditions of scarce natural resources.

3. Idea of effective economic development using nontraditional economic criteria.

4. Control of health, equal access to technologies, food, clean water, security for all humans.

5. Necessity to implement initiatives aimed at improvement of human life [44].

UNEP strategy, which is being implemented today, is a medium-term strategy for 20142017. The strategy is focused on the following issues, which are included in its operating tasks and subprograms: climate change; disasters and conflicts; ecosystem management; environmental governance; chemicals and waste; environment under review. The strategy is targeted at supporting partners and other stakeholders alike; it comprises four interrelated areas: - keeping the world environmental situation under review; - providing policy advice and early warning information, based on sound science and assessments; catalyzing and promoting international cooperation and action, including strengthening technical support and capacity in line with country needs and priorities; - facilitating the development, implementation and evolution of laws, norms and standards and developing coherent interlinkages among multilateral environmental agreements. UNEP's key goal for the period of 2014-2017, in terms of a medium-term strategy, is "to catalyze a transition towards low carbon, resource efficient and equitable development based on the protection and sustainable use of ecosystem services, coherent environmental governance and the reduction of environmental risks". In order to achieve its goals, UNEP strategy will be based on its leading role in the environmental protection activity of the United Nations and beyond, according to the outcome document of the UN Conference on Sustainable Development (Rio+20).

Essentially, UNEP increases its efforts to bring coherence and synergy to the manner in which the United Nations system addresses environmental issues. This implies strengthening UNEP's leading role in the development of environmental strategies within the UN framework of actions at the national, regional and global levels in order to maximize the impact of environmental development and to ensure accessibility of UNEP services and products to the public. This will enhance strategic partnership relations between UNEP, governmental bodies and major environmental groups to change or affect environmental processes through participation of all relevant stakeholders.

UNEP works in the following fields: early warning and assessment of conflicts, technology, implementation of environmental policy, production and economy, environmental law and agreements, regional cooperation, communication and public information, global environmental protection. 
UNEP promotes the environmental law in order to approach sustainable development. In particular, it supports the government and the global community in developing and adopting regulations and laws in this sphere, and also multilateral international agreements. Besides, the Program provides the technical support and training for developing countries with growing economies. Since 2010 UNEP has defined a new strategy with the focus on six areas: climate change, ecosystem management, disasters and conflicts, environmental governance, harmful substances and hazardous waste, resource efficiency, sustainable consumption and production.

The main UNEP body is the Governing Council, which comprises 58 member-states, elected for a period of four years. The role of the Council is to set out development trajectories and work fields for various UN environmental programs. Another objective is to disseminate ideas about cooperation on environmental issues among UN member-states.

The UNEP secretariat accounts for more than 890 employees. More than the half of them come to work by being outsourced from other countries. The secretariat is in charge of implementing UNEP programs; it is responsible for allocating financial receivables and budget. This Program is funded by charity donations primarily from member-states.

UNEP concentrated on efforts to support adaptation to climate change. This implies awareness raising and state potential in order to assess countries' vulnerability and adaptation to climate change, ensuring the political and legal support to member-states to help them apply the knowledge. This will illustrate how adaptation can improve society's resilience to climate change through this support. As a result of this UNEP's activity vulnerability to climate change was identified and assessed in a number of countries, i.e. China, Mozambique, Senegal and Turkey. UNEP also helped the Russian Federation work out the low carbon scenario of the energy efficiency plan.

UNEP financial tools can be divided in the following types:

1. "Environment Fund",

2. Earmarked contributions,

3. Regular UN budget, and project funding opportunities.

Resulting from the Conference Rio+20, in December 2013 the UN General Assembly approved of UNEP budget boost up to $\$ 21 \mathrm{mln}$ for a two-year period (2014-2015). According to the Resolution of the General Assembly GA 67/213 of December 2012, additional funding will be complemented and targeted at enhancing and exploring the UNEP potential to fulfill stimulating and coordinating functions at global, regional and subregional levels [12].

Up to 2013 the percentage of the UN regular budget for the Environment sphere had been declining. However, the recent UN General Assembly made a decision to increase costs for the Environment sphere up to $0.67 \%$ of the total budget for 2014-2015. Earmarked contributions aim to underpin the above-mentioned UNEP functions, and they are made by member-states, UN institutions and other organizations, nongovernmental bodies and physical entities, to support particular events, services and projects.

Thus, UNEP is responsible for: managing the usage of environmental information, providing early warning information, assessing the impact of various factors on the environment, systems of geographical information, strategic assessment of the environment etc. - total 40 points. In order to achieve the results there were elaborated Functional Programs. They include: collecting information on the environment, assessing the information, early warning, developing the environmental policy and environmental law, implementing the environmental protection policy, technology, industry and economy.

Today UNEP is the main UN environmental body that deals with global environmental issues and implements UN strategies addressing to UN environmental issues. Since it was established, UNEP has made a significant contribution to the development of international environmental law. The Organization was the first to define scientific environmental concepts and to work out legal strategies. Additionally, environmental issues are in the focus 
of such specialized institutions as ECOSOC, UNESCO, FAO, WHO, IAEA. However, UNEP is the organization which has a complex approach to environmental issues.

The establishment of UNEP marked involvement of the international community in solving environmental problems, developing environmental policy and diplomacy.

Environmental sustainability is targeted at the support of global life systems for an uncertain period. In its most popular interpretation environmental sustainability is a desired attribute of any model or human activity, which is part of the evolution. This is the form of evolution which aims to achieve the goal of environmental sustainability.

The theory was put forward as the response to the occurrence of humanity problems. These are such global problems as the threat of environmental disaster, demographic problems caused by overpopulation, a rise in technogenic disasters, social conflicts, economic inequality, new diseases etc.

At present, the world community supports the idea of possible coexistence of sustainability and economic growth. The concept of sustainable development arises from a worldview which sees the survival, progress, and continued maintenance of the human community as dependent on the continued health and viability of the earth's life support systems [15]. The term "sustainability" is derived from the Latin root «sus-tinere», which means "support" or "under-hold", in other words, robustness and durability over time. Therefore, sustainable development represents a paradigm that seeks to protect the planet's life support systems to ensure longevity for humans and other biological species.

Sustainable development can be defined as the process of strategic changes in our social systems and institutions in order to achieve sustainability. Some believe that "development" means progress in social well-being or improvement in the quality of life [13]. Others criticize this theory. Sustainable development is a controversial and thought-provoking concept. To respond to the challenge of working out strategies in which all members of the human family can live satisfying lives within the means of nature (William Rees's definition), would require collaborative efforts from a multiplicity of talents: experts, thinkers, scientists, practitioners, business leaders, farmers, governments, and citizens.

The fundamental premise that underpins the concept of sustainable development is that the peoples of the world depend for their survival on an ecological system that is both global and finite. Therefore, observing nature's limits is important in order to prevent an irreversible depletion of the life support systems. Until recently, the concept of the earth as a finite system was not easy to understand and convey, for the earth had always seemed so vast and limitless. The advent of space travel brought a new awareness. Some astronauts noted the rising smoke from the burning of the Amazon forest, and others the high-energy use portions of the earth's surface literally glowing at night.

The image of the earth from space provided a first glimpse of the "big picture of sustainability" because it showed the limits and vulnerability of earth's life support systems, and made clear the global environmental impacts of human activities.

The Agenda for the XXI century has covered most global problems of humanity, which prevent sustainable development, and provides measures and tools for solutions to these problems.

Despite the accuracy, comprehensiveness and importance of tasks on the Agenda 21, some researchers find the document insufficient. Firstly, the problems presented in the document were not classified according to their significance and priority, which could have ensured sequence in their implementation and solved some urgent problems. Secondly, the researchers mentioned optionality of principles in the document. Besides, in someone's opinion, Agenda 21 was adopted in the interests of the "golden billion" in order to distract attention from urgent problems. Thirdly, the document did not come up with suggestions how to review fundamentals of humanities (philosophy, economics, political science, sociology etc.). 
Later we will highlight the results of Agenda 21. It is worth noting that all the countries enabled working out and implementing national programs to shift to sustainable development. These countries are the Netherlands and Australia (1992), Great Britain (1994), USA and Russia (1996), Baltic States (1998), China (2003). In 1993 the EU set forth the Fifth Environmental Action Program "For Sustainable and Ecological Development".

The UN Conference in Rio de Janeiro was followed by a number of UN conferences on sustainable development: the World Conference on Human Rights in Vienna (1993), the International Conference on Population and Development in Copenhagen (1994), the World Conference on Women in Beijing (1995), Rio+5 Conference in New York (1997). In order to achieve goals of Agenda 21 in the sphere of biodiversity and conservation of genetic resources there were adopted the following programs: DIVERSITAS (aimed at coordination of research, 1991), BioTrade, GBIF (open-data infrastructure aimed at providing access to data about all types of life on Earth, 1996) etc. In 2000 the UN Millennium Declaration was adopted at the Millennium Summit.

Obviously, the most important event of the New Millennium was the second World Summit on Sustainable Development in Johannesburg (South Africa, 2002). The Summit gathered together not only government officials, but international and nongovernmental organizations, individuals and researchers. Discussions covered five priority areas: water, sanitation, energy, health, agriculture and biodiversity. The outcome documents of the Conference were the Johannesburg Declaration on Sustainable Development (political declaration) and the "Plan of Implementation of the World Summit on Sustainable Development". The special focus of the documents is made on eradicating poverty. The problem of poverty leads to instability, criminal growth, moral degradation. The lack of satisfactory living conditions makes people susceptible to religious fanaticism and extremism. Poverty is expected to be eradicated if poor people are provided with the affordable access to food, land, education and healthcare. The access should be equal regardless of gender, race, beliefs and other differences. The documents offer such measures as the transfer of sustainable energy technology (biomass energy, wind power) to developing countries, the transfer of knowledge about sustainable agricultural production; the combat against desertification through improving agricultural techniques, improvement of access to sanitation and clean water (toughening standards in governmental institutions). Besides, member-states agreed to reduce the number of slum dwellers by 100 million people by 2020 . Achieving global sustainable development, all countries should promote sustainable consumption and production patterns through long-term planning, education, sharing experience, standards, bans, efficiency rise. It was the first time when the globalization problem had been considered on that scale.

In 2007 the General Assembly adopted the Declaration on the Rights of Indigenous Peoples, and the UN General Assembly declared the United Nations Decade (2010-2020) for Deserts and the Fight against Desertification.

\section{Findings}

According to international research, Rio +20 is a big disappointment, especially if to consider it in terms of accelerating global environmental degradation [19]. However, environmental degradation is not the only criterion: poverty, hunger, lacking access to clean water, food security, unemployment and low quality of healthcare - are a priority; such problems should be tackled through the general development of countries. Importantly, these problems become relevant during economic downturns.

The mandate agreed at Rio +20 for the creation of the goals stipulated that the goals should achieve an appropriate balance between the economic and environmental dimensions of sustainable development. It is unequal allocation of benefit, depending on the development 
of countries, that prevents the latter from achieving the balance [41,26]. The Conference Rio+20 did not solve the problem of countries' unequal involvement in the environmental protection activity. The economic situation has not improved for the recent 20 years. Consequently, Russian and international science analysts share the opinion that Rio +20 was the least effective environmental conference.

The UN is criticized for its inability to make a progress in solving environmental issues via numerous conferences [5]. However, it is necessary to understand that only conferences cannot achieve the results of sustainable development. It is an unrealistic view on the UN activity. If to consider UN gatherings pragmatically, they can be interpreted as the tools for managing economic, social and environmental aspects, or the foundation for extensive cooperation. For instance, Stockholm Conference encouraged countries to take legal and organizational measures at the level of national legislations, including setting up ministries.

Great efficiency of the UN Conference on Environment and Development 1992 set a high level of expectations from the Conference 2012. The success of the former was caused by high efficiency and offered a lot of hope to the latter. It is worth noting that 1992 saw five basic outcome documents: the Rio Declaration, Agenda 21, the Statement of Principles on the Management, Conservation and Sustainable Development of All Types of Forests, the Convention on Biological Diversity, the Framework Convention on Climate Change. Therefore, the results of such a great-scaled event in 2012, compared to the Summit 1992, seemed rather moderate.

Russian researchers Los V.A. and Kasyuk A.Y. mark that on finishing the "sustainable double decades" (1992-2012), the global community did not manage to harmonize economic, environmental and socio-cultural parameters in civilization dynamism. Among other important factors they state conflict of civilizations, socio-environmental processes, life quality, demographic and economic conditions [7].

Participants of the conference in Rio de Janeiro in 2012 accepted only one resolution: "The Future We Want" [2]. This document contains six large blocks of the announcements made by participants concerning different aspects of sustainable development. The sections are: 1) our shared vision; 2) Confirmation of political commitment; 3) "Green" economy within sustainable development and poverty eradication; 4) Institutional framework of sustainable development; 5) Action agenda and follow-up measures; 6) Implementation means. In total, the text has 283 paragraphs. The body of the document is significantly formed with announcements, requests, and statements of facts. Assurances in following the course, earlier confirmed with international treaties, prevail. Also, the conference resulted in the outcome document establishing the Open Working Group which should help in forming the new agenda until 2030. The international community managed to work out a "consensual platform".

However, when analyzing the text of the final document, it is evident that in many paragraphs it is stated: "we confirm commitment" - already in paragraph 1 about 200 terms are admitted. "Governments admitted but did not promise to amend" [3]. That is exactly how the attitude of the majority of Russian scientists toward the results of the conference can be shortly described.

Poor results of the conference in Rio de Janeiro can be explained by many factors. A considerable part of fault lies with the United States of America. Without its active participation, the progress cannot go beyond solving procedural matters. Particular steps are required from the USA: first of all, the decline in production of world resources and their consumption per capita. For successful application of the sustainable development concept, a leader is needed and the USA could become one. There appears a need in a more differentiated estimation of responsibility of the developed and developing countries.

The greatest winners after the conference in Rio de Janeiro are large corporations that were interested in maintaining a status quo because for them it meant continuation of forced 
production of fossil fuels, intensive agriculture, and the absence of notable responsibility for environmental intervention and thus huge income in the short term. The situation is aggravated by the fact that many countries are weakened by the consequences of the economic crisis in recent years and sustainable development is not a top-priority direction when the main task is to avoid an economic collapse of the country [6].

However, though the results of the conference were disappointing for some researchers such as F. Biermann and F. Pearce [17, 33], generally it served as an important factor reflecting global development since the first summit. One of the features of this development is a growing diversity among the countries, which are still called "developing". Within the context of these changes, the term "developing countries" should be used more carefully. Obviously, these terms are convenient for describing geographical location and economic status of countries but it is unwise to suggest that the counties within the concept of developing ones are all similar. It is important to understand that the universal term implies danger and breaks all efforts to achieve sustainable development in the world. Besides, using a unified notion to name a number of different countries creates a negative image of the developing world as poor countries lacking in desire and means for sustainable development and being victims of high resource consumption in the developed countries. But in fact, they are victims of their own bloc that chokes the progress [23].

It does not mean that the developing world is no longer a significant category. It is still vitally important in a geopolitical sense as an indicator of the collective identity and as a political bloc, which continues to show a very unified position towards sustainable development. There is also an opportunity to express a unified position of the countries that still have an extremely high degree of poverty, underdevelopment, and marginality.

The very idea of the sustainable development policy contributed to the creation of the united developing world. Nonetheless, after 25 years since the first conference in Rio de Janeiro, it becomes more obvious that supporting this idea is not always the best way to face the challenges, which appear in the process of formulating a unified global environmental policy. There are many developing worlds, and not just one. Internal diversity is as important as external one. The acknowledgement of diversity and the search for solution to this issue are the main tasks on the way to sustainable development.

The reality is that Rio +20 will not go down in history as a significant event like it was with the first conference in 1992, because in 2012, no structural decisions were made, only procedural. In many aspects, Rio +20 is a sobering reflection of the political world balance and the influence degree of dominant players. However, taking into account the economic and political framework of the conference described before, it would be extremely unreasonable to expect any landmarks, which would help reaching new heights in negotiations that countries have been conducting within many years at specialized forums.

A sharp shift in the roles of countries in this conference also took place. Managing markets with the purpose of achieving long-term results in sustainable development appears extremely difficult due to the USA's position on the side of the developing countries in a greater degree than on the side of the EU because of its unwillingness to take responsibility for interfering with global market relations.

As it was already noted, the only result of the UN Conference on Sustainable Development had become the outcome document "The Future We Want". Possibly, the best thing that can be said about this document is that it represents a synopsis of different concepts for sustainable development at the highest political level. With all its drawbacks, the final result of the work provokes certain interest. At the least, the documents is a part of the ongoing global discourse on how to collectively counter economic and environmental problems.

It also should be noted that in general all goals of the Agenda were achieved. Poverty reduction and the rationalization of consumption were ineffective, the world population 
continues to grow (7.4 bln in 2016) and the problem of overpopulation intensifies. The destruction of flora and fauna did not stop, the problems of water and air pollution, global warming, and desertification are aggravated. The majority of world population still does not know about the sustainable development concept and the need of its implementation. Accepting the Kyoto Protocol (1997), aimed at the reduction of greenhouse gas emission to the atmosphere, did not have the desired effect. The USA still has not ratified this document; $\mathrm{CO} 2$ emissions continue to increase.

Thus, the tasks of sustainable development by 2015 were not fully completed. The majority of economic, social, and environmental problems of the end of the last millennium still threaten humanity in the XXI century. For their solution, the world community continues to adopt international documents in the area of sustainable development.

In September 2015, at the history-making summit in the UN Headquarters in New York City, world leaders adopted the Agenda for sustainable development until 2030, based on the Millennium Development Goals (MDG). The document officially came into force on 1 January 2016. It includes 17 goals and 169 tasks in the area of sustainable development (SDG) [10], which maintain balance of the three components of sustainable development: economic, social, and environmental ones. The countries pledge to make all efforts to implement them in the next 15 years.

\section{Conclusion}

Global environmental problematics emphasizes the necessity of a new approach to knowledge, which will expand our opportunities in problem solving by studying and observing long-term and cumulative effects of various events. John Robinson and John Tinker developed a very useful system definition of sustainability as a creative, systematic, and complex answer to the three "imperatives" [38]:

1. "Ecological imperative" should remain within the bounds of the biophysical ability of the planet.

2. "Economic imperative" is providing and maintaining an appropriate economic living standard for all people.

3. "Social imperative" is the provision of social structures, including management systems which effectively promote and maintain social values and culture.

A sustainable world should cater to the basic needs of all people who live today, not ruling out the ability of future generations to meet their needs. The technological ability to see the Earth from space freed humanity from the tendency of considering problems hastily, including the ones of environmental and social nature, from narrow local perspective. Pollution knows no political borders; environmental contamination problems concern all countries of the world. No single country can isolate itself from social upheavals, regardless of their origin. Technologies made the state of humanity visible in every corner of the world, today more than ever. New global awareness has revealed urgency and complexity of many social problems and connects every country, every economy sector, every person, in present and future, to the same problem in the area of sustainability. All our environmental support systems, including our social and economic systems, are globally interconnected and interdependent.

According to the analysis of difficulties of applying the sustainable development concept, it is possible to conclude that with all its attractiveness there is a great number of obstacles to its implementation. Many factors impede the implementation of the sustainable development policy. Thus, R. Perkins specifies among them uneven economic growth, diversification of the sustainable development problem, geopolitical diversity, and a varying management potential [35]. 
The main problem lies in the difficulty of applying the same theory for all countries. For example, some limitations for the developing countries can imply the impossibility of economic growth without external assistance. For this very reason, a high level of cooperation in the world community is required to achieve sustainable development in the world.

The UN conferences are based on sovereign equality of countries and the principle of a universal multilateral dialogue. The UN Chapter gives member states a formal right to participate in debates and solution development on equal terms. Such an approach to organizing conferences is connected with the idea that a wider membership is more legitimate [25] . It allows expressing a broad range of opinions and contributes to making more rational decisions which provide "the autonomy of many and not few" [22].

Supporters of the UN conferences, who adhere multilateralism, claim that they fulfil a wide range of administrative functions [19, 20, 21, 27, 40]. The conferences serve as important instruments for determining global priorities, increasing the information level, and focusing attention on the issues, which sometimes do not get a detailed consideration that they deserve.

In his respect, the conferences are important platforms for formulating problems, creating new legal principles and norms, supporting establishment of new organizations, generating and distributing information, and also determining norm of behavior. The conferences also function as political arenas, connecting a wide range of state and non-state actors which can exchange their opinions and interests even in the case of inability to cooperate with each other [36].

Nevertheless, it is difficult to estimate the significance of a conference right after its ending. The importance of a conference is often connected with its ability to influence the political agenda and to administer follow-up activities at other forums more than with what happens at the meeting itself. That is exactly why many supporters of the UN conference format emphasize that it is necessary to study their direct and indirect influence within longer periods of time. For example, Stockholm Conference of 1972 induced institutional changes in legislations of many countries. And the first and second waves of establishing Ministries of Environmental Protection in the world came after Stockholm Conference and Rio de Janeiro Conference of 1992 respectively [30].

On the contrary, critics of mega-conferences claim that a large number of participants prevent performing actions [31]. The criticism of large meetings led to discussion of alternative structures, as well as to a wider use of small venues. In some cases such proposals are lucrative: large countries that have access to forums such as G20, know that they will just the same participate in negotiations (and even can experience an increase in their authority) on a smaller scale.

Some sceptics criticize the UN conferences for being too resource-intensive. They require preliminary and long planning and receiving guests just to get global political promises that will be soon forgotten by governments and national politicians [14, 25]. Others criticize them for serving to strengthen the current political system and its inequalities instead of promoting more fundamental changes [16]. The growing global economy has increased living standards for broad segments of the population but continuing poverty and other social problems, as well as unprecedented use of resources and environmental degradation cause huge problems in the management area.

The UN system of organizing large conferences on environment and development, the latest remarkable examples of which are the Rio+20 Conference and the Summit on Sustainable Development 2015 in New York City, is criticized for its "inability to provide noticeable real progress". The criticism touches upon the issue of what can be reasonably expected from global conferences. Certainly, if hoping for them to solve the sustainable development problem, they will always be considered unsuccessful or even failed. 
In many respects, it is an unrealistic vision of what the UN forums can achieve. At best, these meetings can help to determine and administer economic, social, and environmental programs and to lay the basis for broadening of cooperation. During their history, these conferences have played an important role of internal activity initiators. Stockholm Conference of 1972 inspired many countries to think about environmental conditions and to take legal and organizational steps, such as establishing Ministries and Agencies of Environmental Protection. Similarly, the following conferences made countries consider the issue of how to solve problems of sustainable development at the national and regional levels.

The main indicators of environmental conditions and human well-being reflect a dubious situation. Today, the world is much better and much worse than in 1972. Many global environmental trends are of negative nature, including the increase of greenhouse gas emission, the continuing decline in biodiversity, the reduction of fish stock, and higher levels of waste. By contrast, there has been a steep reduction in the emission of ozone-depleting substances and in the oil contamination of the sea [43]. The indicators of the population life quality are also heterogeneous. Life expectancy has increased, the health and education levels have grown and the access to primary goods and services has improved in comparison with the situation forty year ago [28]. Infant mortality is declining, the spread of tuberculosis is stopping, and malaria mortality rate is also falling. Along with that, the number of people living in deprived areas continues to grow and more than 600 million people do not have access to safe drinking water and basic sanitation [42].

In the face of this extremely difficult and challenging situation, the UN conferences remain important forums for the presentation of global problems and transparent discussions. Just like the documents of the previous conferences, "The Future We Want" (the outcome of the Rio+20 Conference) and "The 2030 Agenda for Sustainable Development" (the outcome of the Summit on Sustainable Development in New York City in 2015) are also quite unclear, especially in respect of how to switch from theory to practice.

Strengthening the UNEP mandate seems unlikely as well as the following summits leading to significant institutional changes. It is perfectly clear that the long-term influence of the UN Conferences is largely connected with how state, private, and civic associations ready to reform political and economic institutions [17].

Establishing the UNEP and the Sustainable Development Commission made countries anticipate the creation of additional resource-intensive UN Organizations. Instead, the political debates gradually came over to how it is better to coordinate existing forums and organizations. Dominant discussions on reforms show the dependency on institutional paths of development because they are focused on promoting gradual reforms and not on how to change the system fundamentally. However, even these debates are politically controversial, since some national interests have changed over the past forty years while others have remained virtually the same.

A better progress was achieved in the area of human development, mostly due to the processes not included in the conference system. The "Millennium Development Goals" show that the UN initiatives can promote real progress. Some goals are achieved, while some of them are not. Learning positive and negative lessons on how the "Millennium Development Goals" were formulated and implemented, the humanity can use this experience when implementing "The 2030 Agenda for Sustainable Development"[39]. Unlike the "Millennium Development Goals", it covers not only developing countries but also the rest of the world.

Taking into account the fact that global environmental problems have a very complex manner of occurrence and do not have a simple solution, there is no point in declining the developed strategies. Solving the environmental problems requires many financial resources and influence. Gradually, the humanity is adapting to the thought that safe future demands starting to fight for it already today. 
It is objective that the UN alone will not be able to solve all environmental problems of our age and to set the world community on the path of sustainable development. However, it has the power of environmental education and promoting ecological awareness. At this stage, distribution of information can particularly influence the future of our planet. The UN does not have a legal basis to oblige countries to implement the sustainable development policy because even the documents produced at the conferences are not mandatory. But this organization can affect the national environment-oriented strategies and effectively influence civic associations all over the world. Hence, it can be stated that today the UN is the only global organization that possesses the required resources to have the ability to positively influence the area of protection of the human rights for favorable environment.

At the same time, no matter how inspiring the growth trend in the number of UN specialized agencies involved in solving the problems of transport, health and the environment, these efforts are clearly not enough. The way out of this situation is the concept of sustainable development, which has been on the agenda of the world community in recent decades. A key aspect of the UNECE strategy in terms of sustainable development is the reflection of environmental and health aspects in transport policy. In the context of the study, it can be concluded that integrated institutional mechanisms are needed to improve the transport system, environmental protection, and health strategy coordination within the framework of the UN specialized agencies.

\section{References}

1. URL: http://russian.news.cn/2017-01/25/c 136011522.htm (accessed 13.07.2018)

2. URL: http://www.iblfrussia.org/a-conf.216-1-1_russian.pdf.pdf (accessed 08.01.201)

3. V. Gracheva Vest ekolog. obraz. v Rossii. 3(65) (2012)

4. URL:https://documents-ddsny.un.org/doc/UNDOC/GEN/N00/559/53/PDF/N0055953.pdf?OpenElement (accessed 18.01.2018)

5. A. Dolgopolova Molodezh' i nauka. (1) (2013)

6. M. Zomonova, B. Gomoboev Vest. Burjat. Gos. univer. (1) (2012)

7. V. Los', A. Kasjuk Politika ustojchivogo razvitija civilizacii: mehanizmy upravlenija global'nymi processami: uchebnoe posobie (2012)

8. URL http://www.unepcom.ru/unep/basedocs/narobi-decl.html (accessed 11.01.201 )

9. URL: https://www.un.org/development/desa/ru/news/nocat-uncategorized/sg-visitsdesa.html (accessed 11.03.2018)

10. URL: http://unctad.org/meetings/en/SessionalDocuments/ares70d1_ru.pdf (accessed 11.07.2018).

11. URL: http://www.unepcom.ru/unep/basedocs/narobi-decl.html (accessed 20.08.2018).

12. URL:https://documents-ddsny.un.org/doc/UNDOC/GEN/N12/491/40/PDF/N1249140.pdf?OpenElement (accessed 20.09.2018).

13. V. Smol'kin Vest. Sev. Federal. Univer. (5) (2014)

14. S. Andresen Handbook of Global Environmental Politics, 2nd edition (2012)

15. D. Bell., Y. Cheung Introduction to Sustainable Development (2009)

16. S. Bernstein The Compromise of Liberal Environmentalism (2001)

17. F. Biermann Environ. and Plan. (2013) 
18. URL: https://treaties.un.org/doc/publication/ctc/uncharter.pdf (accessed 20.07.2018).

19. R. Clémençon Jour. of Environment and Development (2012)

20. C. Death Environmental Politics (2011)

21. E. DeSombre Global Environmental Institutions (2006)

22. R. Eckersley Global Environmental Politics (2012)

23. R. Falkner, H. Stephan, J. Vogler Global Policy. (2010)

24. URL: http://www.foreignaffairs.com/articles/138031/peter-m-haas/the-road-from-rio (accessed 22.06.2018)

25. E. Hafner-Burton, D. Victor, Y. Lupa American Journal of International Law (2012)

26. D. Held \& A. McGrew Globalization Theory (2007)

27. M. Hjerpe, B. Linnér Climate Policy (2010)

28. Human Development Report 2010: The Real Wealth of Nations - Pathways to Human Development (2010)

29. URL: http://www.pbl.nl/sites/default/files/cms/publicaties/pbl-2012-the-image-modelsuite-used-for-oecd-environmental-outlook-2050.pdf (accessed 22.01.2018)

30. J. Meyer, D. Frank, A. Hironaka, E. Schofer Intern. Organiz. (1997)

31. M. Olson The Logic of Collective Action (1968)

32. D. Orr Ecological literacy: Education and the transition to a postmodern world // Albany, State University of New York (1991)

33. URL:

http://e360.yale.edu/feature/beyond rios disappointment finding a path to the futu re/2547 (accessed 27.07.2018)

34. URL: http://www.wri.org/publication/world-resources-2000-2001 (accessed 17.01.2018)

35. R. Perkins C: Government and Policy 31 (2013)

36. A. Powers Transnational Environmental Law (2012)

37. W. Rees Carrying Capacity and Sustainability: Waking Malthus' Ghost / University of British Columbia. Vancouver (2003)

38. J. Robinson, J. Tinker Reconciling ecological, economic and social imperatives: A new conceptual framework (New York, 1997)

39. J. Sachs From Millennium Development Goals to sustainable development goals (The Lancet, 2012)

40. G. Seyfang Global Environmental Change (2003)

41. J. Stiglitz Making globalization work (New York, Penguin Books, 2006)

42. The Millennium Development Goals Report 2012 (United Nations, 2012)

43. United Nations Secretary-General's High-Level Panel on Global Sustainability, Resilient People, Resilient Planet: A Future Worth Choosing. UN (2012)

44. S. Wood EOLSS, International Sustainable Development Law, I (2001) 